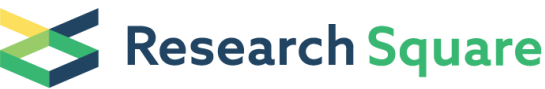 \\ Preprints are preliminary reports that have not undergone peer review. \\ They should not be considered conclusive, used to inform clinical practice, \\ or referenced by the media as validated information.
}

\section{Candidate Biomarkers for the Detection of Serious Infections in Children: A Prospective Clinical Study}

\section{Maria Chiara Pellegrin}

Institute for Maternal and Child Health: IRCCS materno infantile Burlo Garofolo

Arturo Penco ( $\square$ arturo.penco@gmail.com )

University of Trieste: Universita degli Studi di Trieste https://orcid.org/0000-0002-5282-914X

\section{Leonardo Amadio}

Institute for Maternal and Child Health: IRCCS materno infantile Burlo Garofolo

\section{Samuele Naviglio}

Institute for Maternal and Child Health: IRCCS materno infantile Burlo Garofolo

\section{Luigina De Leo}

Institute for Maternal and Child Health: IRCCS materno infantile Burlo Garofolo

Oriano Radillo

Institute for Maternal and Child Health: IRCCS materno infantile Burlo Garofolo

Gianni Biolo

Unit of Internal Medicine, Department of Medical Surgical and Health Sciences, University of Trieste

Nicola Fiotti

Unit of Internal Medicine, Department of Medical Surgical and Health Sciences, University of Trieste

Filippo Mearelli

Unit of Internal Medicine, Department of Medical, Surgical and Health Sciences, University of Trieste

\section{Marco Rabusin}

Institute for Maternal and Child Health: IRCCS materno infantile Burlo Garofolo

\section{Egidio Barbi}

Institute for Maternal and Child Health: IRCCS materno infantile Burlo Garofolo

\section{Lorenzo Monasta}

Institute for Maternal and Child Health: IRCCS materno infantile Burlo Garofolo

\section{Research}

Keywords: Serious bacterial infections, Pediatric, Diagnosis, Biomarkers, Children

Posted Date: November 25th, 2020

DOI: https://doi.org/10.21203/rs.3.rs-113391/v1 
License: (c) (i) This work is licensed under a Creative Commons Attribution 4.0 International License. Read Full License 


\section{Abstract}

BACKGROUND: Serious bacterial infections (SBI) in children are still associated with considerable morbidity and mortality. Early identification of SBI in children presenting with fever and/or signs of systemic inflammatory response (SIRS) remains challenging, as clinical presentation may be subtle, and the role of laboratory markers is still debated. The purpose of the present study is to evaluate the diagnostic role of established and candidate blood biomarkers for the early discrimination of SBI in pediatric patients presenting with fever and/or SIRS criteria.

METHODS: Children who met SIRS criteria and had the clinical indication to perform blood sampling at the first medical evaluation were consecutively enrolled. A panel of biomarkers was performed at enrolment, including C-reactive protein, procalcitonin, white blood cell count (WBC), absolute neutrophil count (ANC), interleukin (IL)-6, IL-8, IL-10, human terminal complement complex (C5b-9), PlasmalemmaVesicle-associated protein 1 (PV-1), Intercellular Adhesion Molecule-1 (ICAM-1), and Phospholipase A2 (PLA2). Bivariate logistic regression models were created to identify significant predictors of SBI.

RESULTS: Among 103 patients (median age 2.9 years, $60 \%$ males), 39 had a diagnosis of SBI (38\%). Significant predictors of SBI were CRP $(p=0.001)$ and ICAM-1 $(p=0.043)$. In the subgroup of patients who were not immunocompromised because of a pre-existing medical condition or therapy (e.g. children with cancer and chemotherapy-induced neutropenia), significant predictors of SBI, were CRP $(p=0.001)$ and ICAM-1 $(p=0.037), W B C(p=0.035), A N C(p=0.012)$ and ANC/WBC ratio $(p=0.015)$. The diagnostic performance of each variable as evaluated by means of ROC curves revealed suboptimal performance for all variables. A model combining CRP and ANC/WBC ratio, however, had a greater diagnostic accuracy than each one of the two variables.

CONCLUSION: This study confirmed the limited usefulness of blood biomarkers for early diagnosis of SBI. WBC, ANC, ANC/WBC ratio, CRP and ICAM-1 showed the best, albeit moderate, diagnostic accuracy as single marker. At present, clinical judgement remains the mainstay for the diagnosis of SBIs in children.

\section{Introduction}

Fever is among the most frequent reasons for medical consultation in children. Between $15 \%$ and $25 \%$ of pediatric consultations in primary care and emergency departments are due to febrile illnesses $(1-3)$. While the majority of children will have mild, self-resolving illnesses, a significant proportion of them may harbor a potentially severe infection. Serious bacterial infections (SBIs) in children are usually defined as bacteremia, meningitis, pneumonia, urinary tract infection, osteomyelitis, suppurative arthritis, soft tissue infections and bacterial gastroenteritis (4). The rate of SBls in children presenting with fever is between $8.5 \%$ and $12 \%$ (5). The risk of SBI is even higher in infants less than three months of age, where it can be up to $20 \%$ (6). Mortality and morbidity due to SBIs are still high. It is, therefore of extreme importance not to miss children presenting with more severe diseases (7-9). The diagnosis of SBI is primarily based on 
clinical presentation. While there are several clinical "red flags" that can aid the clinician to identify children with $\mathrm{SBI}$, it is well-known that their performance is not optimal $(10,11)$.

The role of laboratory markers in the early recognition of SBI is still debated. Several mediators (either pro-inflammatory or anti-inflammatory) are released in the early host response to infectious insults. Some of these biomarkers, such as C-reactive protein (CRP) and procalcitonin (PCT), have been shown to aid in the diagnosis of SBIs in clinical practice, yet their sensitivity and specificity are not optimal (12-14). CRP is probably the most widely used diagnostic and prognostic biomarker, despite its limits, especially its relatively late appearance and its persistence for a longer period (9). PCT could have a greater predictive value for detecting invasive bacterial infections (defined as bacteremia or meningitis), and may be more accurate than CRP in the very first hours since fever onset $(9,14-16)$. Other biomarkers involved in inflammation, including endothelial and complement activation molecules, coagulation, organ dysfunction and apoptosis have been proposed as a possible tool for SBI diagnosis, monitoring and prognosis $(17,18)$. However, their role is still unclear. The present study aimed to evaluate the diagnostic performance of a panel of biomarkers for SBI diagnosis in pediatric patients.

\section{Methods}

\section{Patients and data collection}

This is a monocentric prospective study performed between May 2016 and July 2017 at the Institute for Maternal and Child Health IRCCS Burlo Garofolo in Trieste, Italy. The study protocol conformed to the ethical guidelines of the 1975 Declaration of Helsinki (2008 revision) and was approved by the Institutional Ethics Committee (n. 56/2013). Written informed consent was obtained from parents or legal guardians.

Pediatric patients ( $<18$ years of age) consecutively admitted from Monday to Friday to the Emergency department, as well as full-term neonates ( $<28$ days of age) and children admitted to the HematologyOncology ward of our Institute, were considered eligible if they met the following inclusion criteria: children having at least two out of the four clinical criteria for systemic inflammatory response syndrome (SIRS, Table 1) (19) plus a clinical indication to take a blood sample. Within 24 hours of admission, serum samples were obtained from each patient. Blood cultures were obtained before starting antibiotic therapy. Clinical and laboratory data were collected prospectively without interfering with the clinical practice. The clinical diagnosis, as made by the attending physician at patient's discharge, was recorded, and only patients with a final (clinical or microbiological) diagnosis of an infectious disease were included in the analysis. The main outcome was a diagnosis of SBI. For the purpose of the study, SBIs were defined as bacteremia, meningitis, pneumonia, urinary tract infection, osteomyelitis, suppurative arthritis, soft tissue infection and bacterial gastroenteritis (4). Exclusion criteria were refusal to provide written informed consent and the lack of a clinical indication for blood sampling. The study workflow is illustrated in Fig. 1.

\section{Table 1.}


SIRS criteria according to age (from reference (19))

\begin{tabular}{|c|c|c|c|c|}
\hline Age & $\begin{array}{l}\text { Heart } \\
\text { Rate }\end{array}$ & $\begin{array}{l}\text { Respiratory } \\
\text { Rate }\end{array}$ & $\begin{array}{l}\text { Body temperature } \\
\left({ }^{\circ} \mathrm{C}\right)\end{array}$ & $\begin{array}{l}\text { White Blood Cells } \\
\left(10^{\wedge} 3 / \mathrm{mcL}\right)\end{array}$ \\
\hline$<7$ days & $<$ & $>60$ & $<36 />38$ & $>34000$ \\
\hline $7-30$ days & $<$ & $>50$ & $<36 />38$ & $<5000 />19500$ \\
\hline $\begin{array}{l}30 \text { days- } \\
2 \text { years }\end{array}$ & $<90 />180$ & $>35$ & $<36 />38$ & $<5000 / 17500$ \\
\hline $2-5$ years & $>140$ & $>30$ & $<36 />38$ & $<6000 />15500$ \\
\hline $5-12$ years & $>130$ & $>20$ & $<36 />38$ & $<4500 />13500$ \\
\hline $12-18$ years & $>100$ & $>20$ & $<36 />38$ & $<4500 / 11000$ \\
\hline
\end{tabular}

\section{Biomarkers Determination}

At enrolment, a blood sample for biomarkers was drawn, and serum aliquots were stored at $-80^{\circ} \mathrm{C}$. Determinations of biomarkers were carried out according to manufacturers' instructions and by a single laboratory technician (LA), who was not aware of the clinical presentation of the patient. The nine candidate biomarkers included were: C-reactive protein (CRP), procalcitonin (PCT), interleukin-6 (IL-6), interleukin-8 (IL-8), interleukin-10 (IL-10), secreted type IIA phospholipase A2 (PLA2), human terminal complement complex (C5b-9), intercellular adhesion molecule 1 (ICAM-1) and plasmalemma vesicleassociated protein 1 (PV-1). CRP was analyzed by the Beckman Coulter AU480 System CRP Latex reagent (Brea, CA, USA), with a measuring range of 2-1600 mg/L. PCT was tested using an electrochemiluminescence method (Elecsys Brahms PCT, Roche diagnostic, Mannheim, Germany), with a measuring range of $0.02-100 \mathrm{ng} / \mathrm{mL}$. Soluble PLA2 was assessed with a PLA2 ELISA kit from Cusabio Biotech (Wuhan, China). The detection range was $0.45-30 \mathrm{ng} / \mathrm{mL}$. ICAM-1 was analyzed with ICAM-1 (CD54) SimpleStep ELISA kit from ABCAM (Cambridge, UK). The minimal detectable dose was $1.6 \mathrm{pg} / \mathrm{mL}$. C5b-9 was assessed with TCC C5b-9 ELISA kit from BlueGene Biotech (Shanghai, China). The detection limit was $1.0 \mathrm{ng} / \mathrm{mL}$. IL-6, IL-8 and IL-10 were assessed respectively with Human IL-6 Platinum, Human IL-8 Coated and Human IL-10 Platinum ELISA kit from Invitrogen, by Thermo Fisher Scientific (Waltham, Massachusetts, USA); the detection limits were $0.92 \mathrm{pg} / \mathrm{mL}, 2.0 \mathrm{pg} / \mathrm{mL}$ and $1.0 \mathrm{pg} / \mathrm{mL}$, respectively. PV-1 was measured by ELISA assay (Immunosorbent Assay Kit, Biomatik, Cambridge, Ontario, Canada). The detection range was $0.15-10 \mathrm{ng} / \mathrm{mL}$. All measured results were considered as continuous variables, except for PLA2, which was coded as a dichotomous variable (values above or below $4.5 \mathrm{ng} / \mathrm{mL}$ ).

\section{Statistical analysis}


Continuous variables were reported as medians and interquartile ranges (IQR), and categorical variables as the number of observations and percentages. Comparisons of continuous variables among categories were performed with the Mann-Whitney $U$ test. Associations between categorical variables were assessed with the Fisher's two-tailed exact test. Bivariate logistic regression models were created to identify significant associations with diagnosis of $\mathrm{SBI}$ and to calculate the odds ratio (OR) of unitary increases of each variable with the main outcome. Receiver operator characteristic (ROC) curves were used to the performance of selected biomarkers in identifying patients with SBIs. Since immunodepression (e.g. cancer chemotherapy resulting in neutropenia) could negatively affect the release of several of the tested biomarkers, the statistical analysis was performed both in the whole study sample and in the nonimmunocompromised subgroup of patients. Statistical analyses were performed with Stata/IC 14.2 for Windows (StataCorp LLC, College Station, USA).

\section{Results}

One hundred and three patients were enrolled (males $=62.6 \%$ ) during the study period; 84 in the emergency department, 17 in the hematology-oncology ward, and 2 in the neonatal department. Thirteen (13\%) were infants $<2$ months of age, 17 were immunocompromised subjects ( 16 of them were carriers of a central venous line). A diagnosis of SBI was present in 39/103 patients (38\%) in the whole study population, (33/86 in the non-immunocompromised subgroup). The final diagnoses of patients with SBIs are reported in Table 2.

Table 2. Final diagnoses of SBIs in patients.

\begin{tabular}{|ll|}
\hline Diagnosis of SBI & Number \\
\hline Bacteremia & 7 \\
\hline Meningitis & 1 \\
\hline Urinary tract infection & 4 \\
\hline Pneumonia & 11 \\
\hline Complicated pneumonia & 6 \\
\hline Osteomyelitis & 2 \\
\hline Soft tissue infection & 4 \\
\hline Bacterial gastroenteritis & 4 \\
\hline Total & 39 \\
\hline
\end{tabular}

No deaths occurred during the study period. Biomarkers levels are reported in Table 3 and 4 for the whole study population and the non-immunocompromised subgroup. respectively. Not all biomarkers were available for all patients due to scarcity of available sampled blood in some patients due to difficult blood collection. 
Table 3. Biomarkers levels in the studied population

\begin{tabular}{|c|c|c|c|c|c|}
\hline & All patients & SBI & Non SBI & $\begin{array}{l}\mathrm{p}^{-} \\
\text {value }\end{array}$ & $\begin{array}{l}\mathrm{N} \text { of patients for whom } \\
\text { testing was available }\end{array}$ \\
\hline $\mathrm{n}$ & 103 & 39 & 64 & & \\
\hline Age (years) & $\begin{array}{l}2.9(0.7- \\
7.8)\end{array}$ & $\begin{array}{l}2.6(0.4- \\
9.9)\end{array}$ & $\begin{array}{l}3.7(1.6- \\
12.4)\end{array}$ & 0.029 & \\
\hline $\begin{array}{l}\text { Gender } \\
\text { (males) }\end{array}$ & $62(60)$ & $23(59)$ & $39(61)$ & 0.844 & \\
\hline $\begin{array}{l}\mathrm{CRP} \\
(\mathrm{mg} / \mathrm{L})\end{array}$ & $30(11-83)$ & $\begin{array}{l}66(29- \\
153)\end{array}$ & $16(8-53)$ & 0.001 & 103 \\
\hline $\begin{array}{l}\text { PCT } \\
\text { (ng/mL) }\end{array}$ & $\begin{array}{l}0.3(0.1- \\
1.0)\end{array}$ & $\begin{array}{l}1.0(0.2- \\
2.2)\end{array}$ & $\begin{array}{l}0.2(0.1- \\
0.5)\end{array}$ & 0.056 & 80 \\
\hline $\begin{array}{l}\mathrm{IL}-6 \\
(\mathrm{pg} / \mathrm{mL})\end{array}$ & $\begin{array}{l}18.6(7.6- \\
42.9)\end{array}$ & $\begin{array}{l}27.4(14.4- \\
78.9)\end{array}$ & $\begin{array}{l}13.1(5.2- \\
25.8)\end{array}$ & 0.090 & 99 \\
\hline $\begin{array}{l}\mathrm{IL}-8 \\
(\mathrm{pg} / \mathrm{mL})\end{array}$ & $\begin{array}{l}15.6(10.1- \\
27.8)\end{array}$ & $\begin{array}{l}15.8(10.8- \\
24.3)\end{array}$ & $\begin{array}{l}14.3(9.9- \\
29.4)\end{array}$ & 0.305 & 93 \\
\hline $\begin{array}{l}\mathrm{IL}-10 \\
(\mathrm{pg} / \mathrm{mL})\end{array}$ & $\begin{array}{l}6.0(5.0- \\
22.2)\end{array}$ & $\begin{array}{l}6.0(5.0- \\
19.7)\end{array}$ & $\begin{array}{l}6.7(5.0- \\
24.8)\end{array}$ & 0.905 & 79 \\
\hline $\begin{array}{l}\text { C5b-9 } \\
(\mu \mathrm{g} / \mathrm{mL})\end{array}$ & $\begin{array}{l}0.6(0.4- \\
0.7)\end{array}$ & $\begin{array}{l}0.6(0.4- \\
0.8)\end{array}$ & $\begin{array}{l}0.5(0.4- \\
0.7)\end{array}$ & 0.153 & 69 \\
\hline $\begin{array}{l}\text { PV1 } \\
\text { (ng/mL) }\end{array}$ & $\begin{array}{l}1.8(0.8- \\
3.2)\end{array}$ & $\begin{array}{l}1.8(0.8- \\
3.0)\end{array}$ & $\begin{array}{l}1.7(0.7- \\
3.3)\end{array}$ & 0.644 & 58 \\
\hline $\begin{array}{l}\text { ICAM-1 } \\
\text { (ng/mL) }\end{array}$ & $\begin{array}{l}361.8(291.1 \\
-448.8)\end{array}$ & $\begin{array}{l}486.8(260.6 \\
-636.4)\end{array}$ & $\begin{array}{l}349.7(295.0 \\
-419.9)\end{array}$ & 0.043 & 40 \\
\hline $\begin{array}{l}\mathrm{PLA2}(>4.5 \\
\mathrm{ng} / \mathrm{mL})\end{array}$ & $27(26)$ & $10(26)$ & $17(27)$ & 0.918 & 103 \\
\hline
\end{tabular}

Data reported as median (interquartile range) or absolute number (percentage). P: Mann-Whitney U or Fisher's exact test for the comparison SBI and non-SBI. See text for biomarkers abbreviations.

Table 4. Biomarkers levels in non-immunocompromised patients 


\begin{tabular}{|c|c|c|c|c|c|}
\hline & All patients & SBI & Non SBI & $\begin{array}{l}\mathrm{p}- \\
\text { value }\end{array}$ & $\begin{array}{l}\mathrm{N} \text { of patients for whom } \\
\text { testing was available }\end{array}$ \\
\hline$n$ & 86 & 33 & 53 & & \\
\hline Age (years) & $\begin{array}{l}2.5(0.3- \\
5.6)\end{array}$ & $\begin{array}{l}3.3(1.1- \\
10.5)\end{array}$ & $\begin{array}{l}2.3(0.3- \\
4.7)\end{array}$ & 0.007 & \\
\hline $\begin{array}{l}\text { Gender } \\
\text { (males) }\end{array}$ & $55(64)$ & $22(67)$ & $33(62)$ & 0.141 & \\
\hline $\begin{array}{l}\text { WBC } \\
\left(10^{\wedge} 3 / \mathrm{mcL}\right)\end{array}$ & $\begin{array}{l}11.97(9.41 \\
-18.01)\end{array}$ & $\begin{array}{l}15.37(10.39 \\
-19.88)\end{array}$ & $\begin{array}{l}10.91(9.41- \\
15.20)\end{array}$ & 0.035 & 86 \\
\hline $\begin{array}{l}\text { ANC } \\
\left(10^{\wedge} 3 / \mathrm{mcL}\right)\end{array}$ & $\begin{array}{l}7.95(4.80- \\
13.40)\end{array}$ & $\begin{array}{l}10.10(6.50 \\
-15.40)\end{array}$ & $\begin{array}{l}7.10(4.10- \\
9.80)\end{array}$ & 0.012 & 86 \\
\hline $\begin{array}{l}\text { ANC/WBC } \\
(\%)\end{array}$ & $\begin{array}{l}51.9(20.6- \\
67.3)\end{array}$ & $\begin{array}{l}64.2(0.19- \\
0.76)\end{array}$ & $\begin{array}{l}40.7(20.6- \\
80.5)\end{array}$ & 0.015 & 86 \\
\hline $\begin{array}{l}\mathrm{CRP} \\
(\mathrm{mg} / \mathrm{L})\end{array}$ & $31(10-87)$ & $\begin{array}{l}82(41- \\
153)\end{array}$ & $15(7-52)$ & 0.001 & 86 \\
\hline $\begin{array}{l}\text { PCT } \\
\text { (ng/mL) }\end{array}$ & $\begin{array}{l}0.3(0.1- \\
1.1)\end{array}$ & $\begin{array}{l}1.1(0.3- \\
5.2)\end{array}$ & $\begin{array}{l}0.2(0.1- \\
0.6)\end{array}$ & 0.064 & 63 \\
\hline $\begin{array}{l}\mathrm{IL}-6 \\
(\mathrm{pg} / \mathrm{mL})\end{array}$ & $\begin{array}{l}17.6(6.8- \\
29.4)\end{array}$ & $\begin{array}{l}25.8(11.3- \\
52.1)\end{array}$ & $\begin{array}{l}11.2(4.9- \\
25.8)\end{array}$ & 0.110 & 82 \\
\hline $\begin{array}{l}\text { IL-8 } \\
(\mathrm{pg} / \mathrm{mL})\end{array}$ & $\begin{array}{l}12.8(9.0- \\
18.9)\end{array}$ & $\begin{array}{l}14.2(9.9- \\
18.3)\end{array}$ & $\begin{array}{l}11.9(8.9- \\
20.0)\end{array}$ & 0.696 & 76 \\
\hline $\begin{array}{l}\mathrm{IL}-10 \\
(\mathrm{pg} / \mathrm{mL})\end{array}$ & $\begin{array}{l}8.0(5.0- \\
25.4)\end{array}$ & $\begin{array}{l}6.0(5.0- \\
19.7)\end{array}$ & $\begin{array}{l}8.3(5.0- \\
26.0)\end{array}$ & 0.809 & 64 \\
\hline $\begin{array}{l}\text { C5b-9 } \\
(\mu \mathrm{g} / \mathrm{mL})\end{array}$ & $\begin{array}{l}0.6(0.4- \\
0.7)\end{array}$ & $\begin{array}{l}0.6(0.4- \\
0.9)\end{array}$ & $\begin{array}{l}0.5(0.4- \\
0.7)\end{array}$ & 0.180 & 54 \\
\hline $\begin{array}{l}\text { PV1 } \\
\text { (ng/mL) }\end{array}$ & $\begin{array}{l}2.0(1.4- \\
3.3)\end{array}$ & $\begin{array}{l}1.8(0.9- \\
3.2)\end{array}$ & $\begin{array}{l}2.0(1.5- \\
3.8)\end{array}$ & 0.511 & 44 \\
\hline $\begin{array}{l}\text { ICAM-1 } \\
\text { (ng/mL) }\end{array}$ & $\begin{array}{l}394.6(295.0 \\
-506.1)\end{array}$ & $\begin{array}{l}561.1(340.4 \\
-636.4)\end{array}$ & $\begin{array}{l}366.7(295.0 \\
-419.9)\end{array}$ & 0.037 & 31 \\
\hline $\begin{array}{l}\text { PLA2 (>4.5 } \\
\mathrm{ng} / \mathrm{mL})\end{array}$ & $25(29)$ & $9(27)$ & $16(30)$ & 0.099 & 86 \\
\hline
\end{tabular}

Data reported as median (interquartile range) or absolute number (percentage). P: Mann-Whitney U or Fisher's exact test for the comparison SBI and non SBI. See text for biomarkers abbreviations.

Variables significantly associated with $\mathrm{SBI}$ at patient's admission at bivariate logistic regression were CRP (OR 1.13 [95\% Cl 1.05 - 1.21]; $p=0.001$ ) and ICAM-1 (OR 1.006 [95\% Cl 1.0001 - 1.0118]; p=0.043). An association was also found towards an increased PCT in patients with $\mathrm{SBI}(\mathrm{p}=0.056)$, but it did not reach statistical significance. In the sub-analysis in the group of non-immunocompromised patients, CRP (OR 1.156 [95\% Cl $1.065-1.256] ; p=0.001$ ) and ICAM-1 (OR 1.0069 [95\% Cl $1.0004-1.0134] ; p=0.037$ ) were 
also significantly higher in patients with SBIs as compared to non-SBI patients; in addition, White Blood Cells (WBC) count (OR 1.077 [95\% Cl 1.005 - 1.155]; p=0.035), Absolute Neutrophil Count (ANC) (OR 1.096 [1.021 - 1.171]; $p=0.012$ ) and ANC/WBC ratio (OR 1.032 [1.007 - 1.057]; $p=0.015)$ were significantly higher in the group with SBI than not-SBI (OR for ANC and WBC are calculated as $10^{\wedge} 3 \mathrm{cell} / \mathrm{s} / \mathrm{mcL}$ ). A quasisignificant association between an increased PCT in patients with SBIs $(p=0.064)$ was found also in this group of patients. Multivariate regression analysis could not be performed due to missing values for several biomarkers.

The diagnostic performance of selected biomarkers in identifying children with SBIs were evaluated by means of ROC curves (table 5). Most ROC curves had an acceptable (i.e. between 0.7 and 0.8 ) value for the area under the curve (AUC), thus indicating a suboptimal performance for clinical purposes. We further explored the possibility that a combination of biomarkers could have a greater accuracy to identify patients with SBI. No combination did achieve better performance than single biomarkers when considering the whole study population; however, when the analysis was limited to nonimmunocompromised patients, the combination between CRP and ANC/WBC ratio did result in an improved AUC. This combination was expressed by the following equation:

$y=1 /(1+\operatorname{EXP}(-(-3.337734+2.922786 *(A N C / W B C)+0.14339 * C R P)))$.

A value of y equal or less than 0.22 resulted in $100 \%$ sensitivity in identifying children with SBI, albeit with a $47 \%$ specificity.

Table 5. Area under the ROC curve for selected biomarkers for the diagnosis of SBI

\begin{tabular}{|lll|}
\hline Biomarker & $\begin{array}{l}\text { Area under the ROC curve, all } \\
\text { patients }(95 \% \mathrm{Cl})\end{array}$ & $\begin{array}{l}\text { Area under the ROC curve, non- } \\
\text { immunocompromised patients only }(95 \% \mathrm{Cl})\end{array}$ \\
\hline CRP & $0.75(0.65-0.85)$ & $0.79(0.69-0.88)$ \\
PCT & $0.73(0.61-0.85)$ & $0.74(0.61-0.88)$ \\
ICAM- & $0.64(0.37-0.90)$ & $0.69(0.41-0.96)$ \\
ANC/WBC ratio & $\mathrm{n} / \mathrm{a}$ & $0.68(0.56-0.79)$ \\
$\begin{array}{l}\text { ANC/WBC ratio }+ \\
\text { CRP model }\end{array}$ & $\mathrm{n} / \mathrm{a}$ & $0.83(0.74-0.91)$ \\
\hline
\end{tabular}

See text for biomarkers abbreviations

\section{Discussion}

The utility of biomarkers for the early diagnosis of SBI in children is still debated. The host response to infection is determined by several mediators and different molecules. Many of them have been proposed as possible biomarkers in preclinical or clinical studies, but no gold standard has been identified in pediatric patients, and studies are still relatively scarce $(8,20-24)$. It seems unlikely that one single 
molecule could be used as an optimal biomarker for the diagnosis and management of SBI $(20,25,26)$. To date, no new candidate biomarker (including cytokine/chemokine, cell surface receptors, coagulation and complement molecules, markers of vasodilation or organ disfunction) has established to be more efficient than those already used in the clinical practice (CRP, PCT and WBC, ANC/WBC and the ratio of immature to total number of neutrophils), although some evidence is emerging about some new biomarkers (27-30).

Presently, determination of old biomarkers is less expensive and widely available. In addition to the economic aspect, a possible pitfall, when considering candidate biomarkers, is the timing of their increase and decrease, which can display wide variations. As an example, in infants IL-6, IL-8 and IL-10 are peaking soon as the suspect of sepsis is made, while PCT and CRP are reacting later, with peak concentrations at 8-16 and 16-24 hours, respectively (31). Nevertheless, the exact timing of measure is often challenging to be determined in real-life conditions. Most of the studies on biomarkers in febrile children have been performed to recognize patients with sepsis. Nevertheless, SBI are far more frequent than sepsis. Therefore, identifying a valuable biomarker for this purpose could be extremely useful to direct patient care, avoid unnecessary diagnostic tests and health care resources expenditure, as well as unnecessary antibiotic therapy, and, on the other hand, avoid missing children with possibly severe diagnosis.

In our study, only CRP showed optimal diagnostic accuracy for the diagnosis of SBI, while PCT was only marginally useful. Previous studies have shown some usefulness of PCT as an infection marker and for antibiotic stewardship in adults $(32,33)$. Recently, a meta-analysis evaluating the diagnostic accuracy of PCT as a biomarker of SBI in feverish children concluded that PCT did not have sufficient sensitivity and specificity to definitively rule in or rule out SBI in children, but it had better accuracy than CRP and WBC count in identifying SBI in children, and it could perform better in identifying most severe infections, such bacterial meningitis and sepsis (34). In our study, PCT had only moderate accuracy in diagnosing SBI in children and eventually appeared to perform worse than CRP. CRP is probably the most widely used in the initial workup of SBI. Nevertheless, the use of CRP could be limited by its relatively late rise, which can occur only after 18-24 hours from symptoms onset. WBC and absolute neutrophil counts may rise more rapidly, and are widely used in the routine diagnostic workup of SBI, but they have less diagnostic capacity than CRP or PCT, in particular for ruling out SBI. One study reported that WBC count did not add any additional information over CRP and PCT in a multivariate logistic regression analysis (35). Notably, in our study, ANC/WBC ratio, when evaluated in non-leukopenic patients, had a limited diagnostic performance, as demonstrated by its ROC curve AUC. However, when used in a mathematical combination with CRP, it resulted in greater accuracy than each marker taken alone.

Regarding candidate biomarkers (IL-6, IL-8, IL-10, C5b-9, PV-1, PLA2), our study shows that the effectiveness of these molecules in detecting SBI in children was quite low. The best biomarker among these was ICAM-1. ICAM-1 is expressed during the inflammatory response. It is well established that during the induction and progression of the systemic response, there is an endothelial cell activation, and it is believed that endothelium plays a key role in sepsis. This activation may lead to changes in leukocyte 
trafficking, vascular permeability, inflammation and microcirculatory flow that may contribute to organ damage $(36,37)$. ICAM- 1 is part of the cell surface immunoglobulin superfamily of adhesion receptors that play a role in lymphocyte-mediated adhesion, cytotoxic T-cell activity, antigen presentation and it is also a ligand for macrophage-associated complex (MAC-1) (38). Previous studies found it could have a role in the early diagnosis of sepsis in newborns and infants and may be associated with its severity degree $(38,39)$, while a study on adult patients admitted to the emergency department with sepsis showed an association between levels of biomarkers of endothelial activation and sepsis severity, organ dysfunction and mortality (36). In our study we also evaluated PV-1, an endothelial protein which has a crucial role in endothelial permeability and leukocyte migration both in normal and pathologic conditions (40-42) but no association with SBls was found.

Our study had some strengths, including the prospective design and the evaluation of some biomarkers which had never been tested before in pediatric patients with SIRS. Furthermore, there are only few studies that evaluate biomarkers for the diagnosis of SBIs, while the majority are focused only on the occurrence or the severity of sepsis. Nevertheless, some limitations need to be pointed out. The study was carried out in a diverse real-life setting including emergency department and oncology ward. We therefore had to perform a separate analysis on non-immunocompromised patients (i.e. most patients presenting to emergency department) to avoid possible biases due to immune suppression that could have artificially reduced the performance of some biomarkers. A major limitation of the study was that it was not possible to test all biomarkers in all patients because of scarcity of sampled serum, mostly due to difficult blood sampling in children in the emergency setting; this resulted in loss of statistical ability to evaluate the performance of some biomarkers and prevented the possibility of performing multivariate analysis.

\section{Conclusion}

Our study confirms the limited usefulness of biomarkers for the early diagnosis of SBls in children. Among candidate biomarkers, no one did reach statistical significance, except for ICAM- 1 ; this result should be confirmed in larger studies. For biomarkers already used in clinical practice, our study confirmed their limited predictive value, remarking the fact that, at present, clinical judgement remains the mainstay of SBI diagnosis in the pediatric setting.

\section{Abbreviations}

ANC: Absolute Neutrophil Count; AUC: Area Under the Curve; C5b-9: human terminal complement complex; CRP: C-Reactive Protein; ICAM-1: Intercellular Adhesion Molecule 1; IL-6: Interleukin-6; IL-8: Interleukin-8; IL-10: Interleukin-10; OR: Odds ratio; PCT: Procalcitonin; PLA2: Secreted type IIA phospholipase A2; PV-1: Plasmalemma vesicle-associated protein 1; ROC: Receiver operator characteristic; SBI: Serious bacterial infection; SIRS: Systemic inflammatory response syndrome; WBC: White blood cells count. 


\section{Declarations}

Ethics approval and consent to participate: The study protocol was approved by the "Institutional Ethics Committee" (n. 56/2013). All legal guardians provided written informed consent on admission.

Consent for publication: Not applicable.

Availability of data and materials: The dataset analyzed during the current study is available from the corresponding author on reasonable request.

Competing interests: The authors declare that they have no competing interests

Funding: This study was funded by a grant from the Italian Ministry of Health ("RF 2011-02348364: New biomarkers for early SIRS/sepsis diagnosis in pediatric and adult patients").

Role of the Sponsor: The Italian Ministry of Health had no role in the design and conduct of the study; collection, management, analysis, and interpretation of the data; preparation, review or approval of the manuscript, and decision to submit the manuscript for publication.

Authors' contributions: MCP, EB, OR, GB, NF, FM and MR designed the study. LA, LDL and OR performed laboratory analysis. MCP, AP, SN and LM performed data collection, interpretation and analysis. MCP, AP, $\mathrm{SN}, \mathrm{EB}$ and LM drafted a first version of the manuscript and contributed in writing the manuscript. All authors contributed to revising the manuscript and agreed with its final version.

Acknowledgements: Not applicable.

\section{References}

1. Nelson DS, Walsh K, Fleisher GR. Spectrum and frequency of pediatric illness presenting to a general community hospital emergency department. Pediatrics. 1992;90:5-10.

2. Whitburn S, Costelloe C, Montgomery AA, Redmond NM, Fletcher M, Peters TJ, et al. The frequency distribution of presenting symptoms in children aged six months to six years to primary care. Prim Health Care Res Dev. 2011;12:123-34.

3. Sands R, Shanmugavadivel D, Stephenson T, Wood D. Medical problems presenting to paediatric emergency departments: 10 Years on. Emerg Med J. 2012;29:379-82.

4. Jaskiewicz JA, McCarthy CA, Richardson AC, White KC, Fisher DJ, Dagan R, et al. Febrile infants at low risk for serious bacterial infection - An appraisal of the Rochester criteria and implications for management. Pediatrics. 1994;94:390-9.

5. Huppler AR, Eickhoff JC, Wald ER. Performance of low-risk criteria in the evaluation of young infants with fever: Review of the literature. Pediatrics. 2010;125:228-33.

6. Aronson PL, Thurm C, Alpern ER, Alessandrini EA, Williams DJ, Shah SS, et al. Variation in Care of the Febrile Young Infant, 90 Days in US Pediatric Emergency Departments. Pediatrics. 2014;134:667-77. 
7. Thompson M, van den Bruel A, Verbakel J, Lakhanpaul M, Haj-Hassan T, Stevens R, et al. Systematic review and validation of prediction rules for identifying children with serious infections in emergency departments and urgent-access primary care. Health Technol Assess. 2012;16:1-100.

8. Rautiainen L, Pavare J, Grope I, Tretjakovs P, Gardovska D. Inflammatory cytokine and chemokine patterns in paediatric patients with suspected serious bacterial infection. Medicina. 2019;55:4.

9. Meem M, Modak JK, Mortuza R, Morshed M, Islam MS, Saha SK. Biomarkers for diagnosis of neonatal infections: A systematic analysis of their potential as a point-of-care diagnostics. J Glob Health. 2011;1:201-9.

10. Nijman RG, Vergouwe $Y$, Thompson $M$, Veen M, Van, Van Meurs AHJ, Van Der Lei J, et al. Clinical prediction model to aid emergency doctors managing febrile children at risk of serious bacterial infections: Diagnostic study. BMJ. 2013;346:1-16.

11. Van den Bruel A, Haj-Hassan T, Thompson M, Buntinx F, Mant D. Diagnostic value of clinical features at presentation to identify serious infection in children in developed countries: a systematic review. Lancet. 2010;375:834-45.

12. Yo CH, Hsieh PS, Lee SH, Wu JY, Chang SS, Tasi KC, et al. Comparison of the test characteristics of procalcitonin to $\mathrm{C}$-reactive protein and leukocytosis for the detection of serious bacterial infections in children presenting with fever without source: A systematic review and meta-analysis. Ann Emerg Med. 2012;60:591-600.

13. Van Den Bruel A, Thompson MJ, Haj-Hassan T, Stevens R, Moll H, Lakhanpaul M, et al. Diagnostic value of laboratory tests in identifying serious infections in febrile children: Systematic review. Bmj. 2011;342:1-11.

14. Milcent K, Faesch S, Guen CG, Le, Dubos F, Poulalhon C, Badier I, et al. Use of Procalcitonin Assays to Predict Serious Bacterial Infection in Young Febrile Infants. JAMA Pediatr. 2016;170:62-9.

15. Luaces-Cubells C, Mintegi S, García-García JJ, Astobiza E, Garrido-Romero R, Velasco-Rodríguez J, et al. Procalcitonin to detect invasive bacterial infection in non-toxic-appearing infants with fever without apparent source in the emergency department. Pediatr Infect Dis J. 2012;31:645-7.

16. Barbi E, Marzuillo P, Neri E, Naviglio S, Krauss B. Fever in Children: Pearls and Pitfalls. Children. 2017;4:81.

17. Lacour AG, Gervaix A, Zamora SA, Vadas L, Lombard PR, Dayer JM, et al. Procalcitonin, IL-6, IL-8, IL-1 receptor antagonist and $\mathrm{C}$-reactive protein as identificators of serious bacterial infections in children with fever without localising signs. Eur J Pediatr. 2001;160:95-100.

18. Tavladaki T, Spanaki AM, Dimitriou H, Kondili E, Choulaki C, Georgopoulos D, et al. Similar Metabolic, Innate Immunity, and Adipokine Profiles in Adult and Pediatric Sepsis Versus Systemic Inflammatory Response Syndrome-A Pilot Study. Pediatr Crit Care Med. 2017;18:e494-505.

19. Goldstein B, Giroir B, Randolph A. International pediatric sepsis consensus conference: Definitions for sepsis and organ dysfunction in pediatrics. Pediatr Crit Care Med. 2005;6:2-8.

20. Oikonomakou Z, Gkentzi M, Gogos D, Akinosoglou C. K. Biomarkers in pediatric sepsis: a review of recent literature. Biomark Med. 2020;14:895-917. 
21. Zarkesh M, Sedaghat F, Heidarzadeh A, Tabrizi M, Moghadam KB, Ghesmati S. Diagnostic value of IL-6, CRP, WBC, and absolute neutrophil count to predict serious bacterial infection in febrile infants. Acta Med Iran. 2015;53:408-11.

22. Wong HR, Cvijanovich NZ, Hall M, Allen GL, Thomas NJ, Freishtat RJ, et al. Interleukin-27 is a novel candidate diagnostic biomarker for bacterial infection in critically ill children. Crit Care. 2012;16:R213.

23. Benito J, Luaces-Cubells C, Mintegi S, Astobiza E, Martinez-Indart L, Valls-Lafont A, et al. Lack of value of midregional pro-adrenomedullin and C-terminal pro-endothelin-1 for prediction of severe bacterial infections in infants with fever without a source. Eur J Pediatr. 2013;172:1441-9.

24. Wang $C$, Wang Y, Wang A, Fu P, Yang Y. The diagnostic value of apolipoprotein $E$ in pediatric patients with invasive bacterial infections. Clin Biochem. 2012;45:215-8.

25. Pierrakos C, Vincent JL. Sepsis biomarkers: A review. Crit Care. 2010;14:R15.

26. Mearelli F, Fiotti N, Giansante C, Casarsa C, Orso D, De Helmersen M, et al. Derivation and validation of a biomarker-based clinical algorithm to rule out sepsis from noninfectious systemic inflammatory response syndrome at emergency department admission: A multicenter prospective study. Crit Care Med. 2018;46:1421-9.

27. Vardas K, llia S, Sertedaki A, Charmandari E, Briassouli E, Goukos D, et al. Increased glucocorticoid receptor expression in sepsis is related to heat shock proteins, cytokines, and cortisol and is associated with increased mortality. Intensive Care Med Exp. 2017;5:10.

28. Al Shuaibi M, Bahu RR, Chaftari AM, Al Wohoush I, Shomali W, Jiang Y, et al. Pro-adrenomedullin as a novel biomarker for predicting infections and response to antimicrobials in febrile patients with hematologic malignancies. Clin Infect Dis. 2013;56:943-50.

29. Wong HR. Genetics and genomics in pediatric septic shock. Crit Care Med. 2012;40:1618-26.

30. Mahajan P, Kuppermann N, Mejias A, Suarez N, Chaussabel D, Casper TC, et al. Association of RNA biosignatures with bacterial infections in febrile infants aged 60 days or younger. JAMA. 2016;316:846-57.

31. Bender J, Thaarup J, Varming K, Krarup H, Ellermann-Eriksen S, Ebbesen F. Early and late markers for the detection of early-onset neonatal sepsis. Dan Med Bull. 2008;55:219-23.

32. Reinhart K, Bauer M, Riedemann NC, Hartog CS. New approaches to sepsis: Molecular diagnostics and biomarkers. Clin Microbiol Rev. 2012;25:609-34.

33. Fiotti N, Mearelli F, Ruscio M, Altamura N, Vinci P, Fernandes G, et al. Procalcitonin in early rulein/rule-out of sepsis in SIRS patients admitted to a medical ward. Clin Chem Lab Med. 2014;52:1473-8.

34. Trippella G, Galli L, De Martino M, Lisi C, Chiappini E. Procalcitonin performance in detecting serious and invasive bacterial infections in children with fever without apparent source: a systematic review and meta-analysis. Expert Rev Anti Infect Ther. 2017;15:1041-57.

35. Lacour AG, Zamora SA, Gervaix A. A score identifiyng serious bacterial infections in children with fever without source. Pediatr Infect Dis J. 2008;27:654-6. 
36. Skibsted S, Jones AE, Puskarich MA, Arnold R, Sherwin R, Trzeciak S, et al. Biomarkers of endothelial cell activation in early sepsis. Shock. 2013;39:427-32.

37. Wright JK, Hayford K, Tran V, Al Kibria GM, Baqui A, Manajjir A, et al. Biomarkers of endothelial dysfunction predict sepsis mortality in young infants: A matched case-control study. BMC Pediatr. 2018;18:1-12.

38. Figueras-Aloy J, Gómez-López L, Rodríguez-Miguélez JM, Salvia-Roiges MD, Jordán-García I, FerrerCodina I, et al. Serum soluble ICAM-1, VCAM-1, L-selectin, and P-selectin levels as markers of infection and their relation to clinical severity in neonatal sepsis. Am J Perinatol. 2007;24:331-8.

39. Sosa-Bustamante GP, Amador-Licona N, Barbosa-Sabanero G, Guízar-Mendoza JM, López-Briones S, Mulgado-Águas $\mathrm{Cl}$, et al. Intercellular adhesion molecules and mortality for sepsis in infants younger than 1 year of life. Rev Investig Clin. 2011;63:601-6.

40. Spadoni I, Zagato E, Bertocchi A, Paolinelli R, Hot E, Di Sabatino A, et al. A gut-vascular barrier controls the systemic dissemination of bacteria. Science. 2015;350:830-4.

41. Guo L, Zhang H, Hou Y, Wei T, Liu J. Plasmalemma vesicle-associated protein: A crucial component of vascular homeostasis. Exp Ther Med. 2016;12:1639-44.

42. De Leo L, Naviglio S, Vatta S, Benelli E, Stera G, Santon D, et al. Circulating Plasmalemma Vesicleassociated Protein-1 as a Marker of Celiac Disease-associated Liver Injury. Biomark Med. (In press).

\section{Figures}

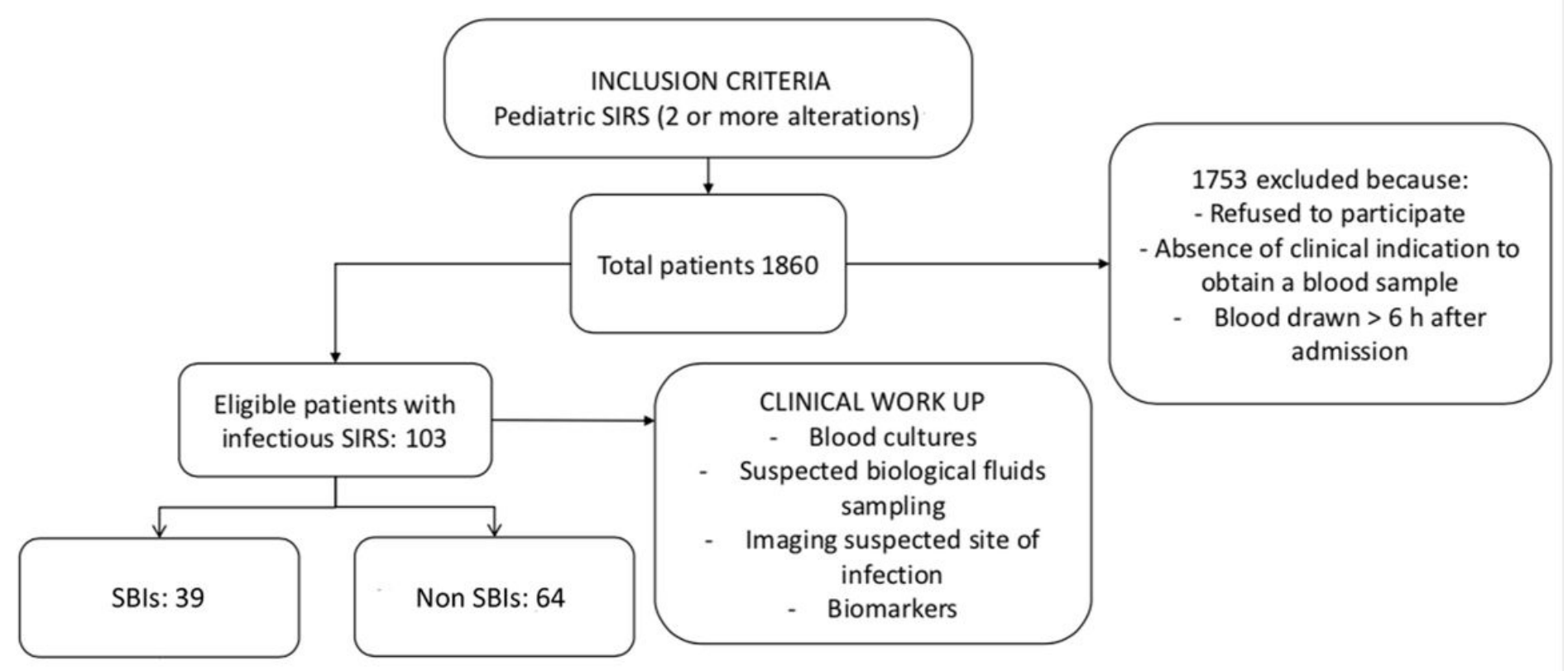

\section{Figure 1}

Study design flow chart. 


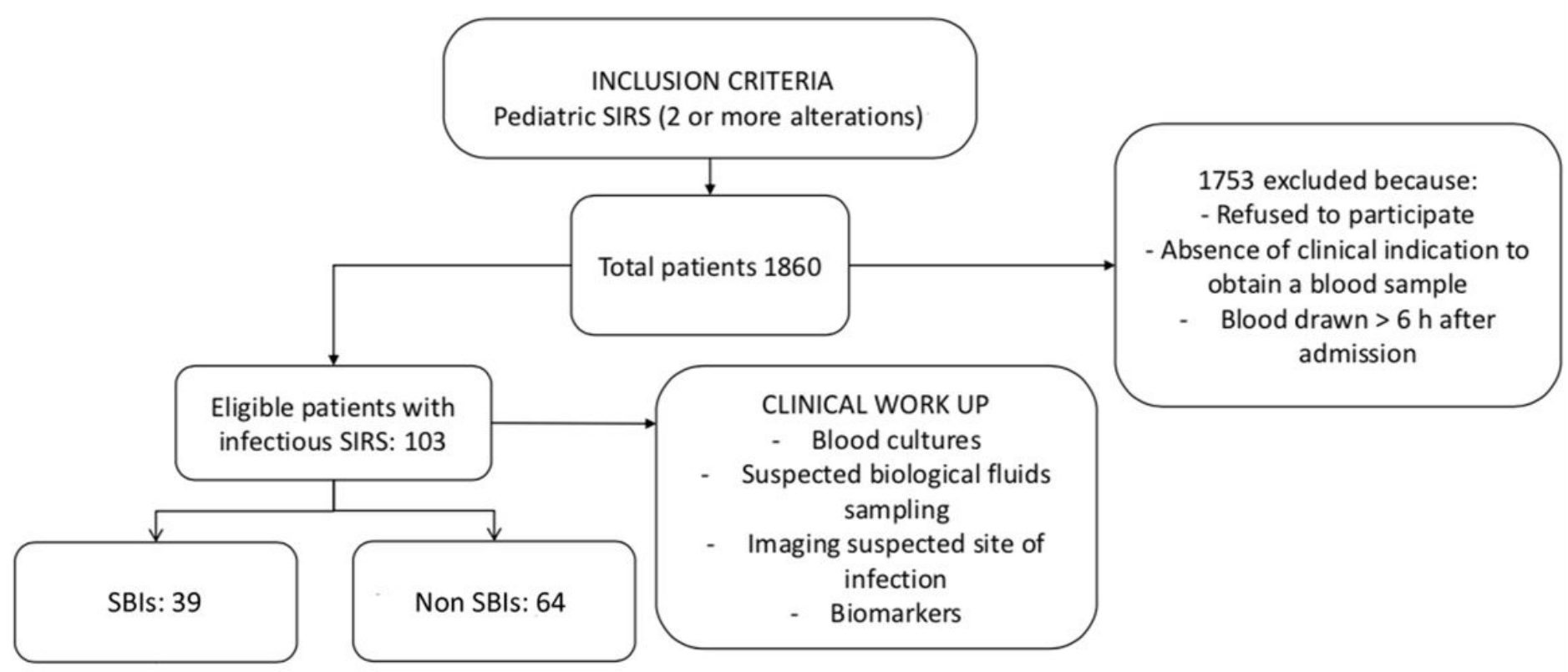

Figure 1

Study design flow chart. 